This is an electronic reprint of the original article. This reprint may differ from the original in pagination and typographic detail.

Author(s): Takala, Pauliina

Title: Students' choice of language and initial motivation for studying Japanese at the University of Jyväskylä Language Centre

Year: $\quad 2015$

Version:

Please cite the original version:

Takala, P. (2015). Students' choice of language and initial motivation for studying Japanese at the University of Jyväskylä Language Centre. In J. Jalkanen, E. Jokinen, \& P. Taalas (Eds.), Voices of pedagogical development : expanding, enhancing and exploring higher education language learning (pp. 279-318). Research-publishing.net. https://doi.org/10.14705/rpnet.2015.000298

All material supplied via JYX is protected by copyright and other intellectual property rights, and duplication or sale of all or part of any of the repository collections is not permitted, except that material may be duplicated by you for your research use or educational purposes in electronic or print form. You must obtain permission for any other use. Electronic or print copies may not be offered, whether for sale or otherwise to anyone who is not an authorised user. 


\title{
15 Students' choice of language \\ and initial motivation for studying \\ Japanese at the University \\ of Jyväskylä Language Centre
}

\author{
Pauliina Takala ${ }^{1}$
}

\section{Abstract}

lective language courses, particularly those starting from the beginner language course offerings of universities. The elementary courses of less commonly taught languages (LCTL), such as Japanese, provide students with the opportunity to acquire, among other benefits, a proficiency that distinguishes them from other job applicants. Ordinary language skills, commonly limited to English only, are today regarded as the default and not as any unique international asset. Even partial knowledge of a less commonly taught language and culture broadens one's worldview and increases cultural understanding. The many years of experience in teaching Japanese have evoked in me the desire to analyse my students' backgrounds, studies and employment. The survey described in this article constitutes the basis for a broader study to be conducted in the future. The purpose of the survey was to collect and analyse data on the faculties and major subjects of students who attend elementary Japanese courses, as well as their language repertoires besides Japanese. Their initial motivation, reasons for the choice of Japanese and plans for the future related to Japan and Japanese studies were analysed.

Keywords: Japanese language and culture studies, beginner level language learning, language choice, motivation, employment.

\footnotetext{
1. Language Centre, University of Jyväskylä, Finland; a.pauliina.takala@jyu.fi

How to cite this chapter: Takala, P. (2015). Students' choice of language and initial motivation for studying Japanese at the University of Jyväskylä Language Centre. In J. Jalkanen, E. Jokinen, \& P. Taalas (Eds), Voices of pedagogical development - Expanding, enhancing and exploring higher education language learning (pp. 337-358). Dublin: Research-publishing.net. doi:10.14705/rpnet.2015.000298
} 


\section{Introduction}

\section{Japanese studies at Finnish higher education institutions and at the University of Jyväskylä Language Centre}

Elective language courses, particularly those starting from the beginner level, constitute their own special group within the communication and language course offerings of a university. The elementary courses of less commonly taught languages (LCTL), such as Japanese, provide students with the opportunity to acquire a proficiency that distinguishes them, for example, from other job applicants. The knowledge of a less commonly taught language and culture broadens one's worldview and increases cultural understanding.

Japanese language and culture can be studied as a major subject at the University of Helsinki's Department of World Cultures and at the Fria kristliga folkhögskolan, a Finland-Swedish folk high school in Vaasa, which operates under the University of Stockholm. The Faculty of Social Sciences at the University of Turku hosts the Master's Degree Programme in Asian Studies, which provides advanced-level Japanese studies. The intermediate studies of Japanese language and culture can be completed as a minor subject at the universities of Eastern Finland and Oulu. In addition, at the language centres or corresponding units of several higher education institutions, such as the University of Jyväskylä Language Centre, students can complete at least elementary courses in Japanese. Smedlund and Uemura (2010) have edited an article collection in which the present-day situation of Japanese teaching and learning in Finland is mapped through expert interviews. Further themes discussed in the collection include the role of Japanese culture and language in a variety of contexts.

Japanese studies have retained their popularity at the University of Jyväskylä Language Centre in recent years despite the natural disasters and economic upheavals Japan has faced. This is partly explained by the general popularity of Japanese culture, but also by the fact that student and researcher exchange between our countries has increased. The Japanese writing system has been 
experienced as difficult to handle and understand, but modern IT devices and applications have considerably facilitated its reading and writing.

The University of Jyväskylä Language Centre has offered Japanese courses since 1990. Over the past 25 years, the popularity of the centre's Japanese language and culture studies has steadily grown. Students can currently complete a total of 30 ECTS credits in Japanese, consisting of six language-focused courses and one cultural course. Two elementary summer courses have usually been organised with similar contents as the elementary winter courses. In the academic year 2013-2014, a total of 112 students studied Japanese in nine different courses at the Language Centre. Since early 2013, the Language Centre has provided students with the opportunity to compile individual Japanese courses into a minor subject - the basic studies in Japanese language and culture. This has further increased the popularity of the subject.

As Juha Janhunen, Professor of East Asian Studies from the University of Helsinki Asian Studies states, high-quality teaching in students' mother tongue is crucial at the initial stage of learning a foreign language, whereas staying and studying in the target country becomes important at a later stage (Cairns 2010). This view is shared by Annamari Konttinen, University Teacher from the University of Turku Centre for East Asian Studies (Smedlund \& Uemura 2010). Continuing one's studies in Japan after the Language Centre courses is a real option: the University of Jyväskylä has six bilateral student exchange agreements with partner universities and several other faculty- and department-level cooperation agreements with universities in Japan. These internationalisation opportunities can be utilised by students as well as staff in order to enhance their language and cultural competence.

\section{The research problem and its background}

As a university teacher of Japanese language and culture, I encounter heterogeneous student groups. Large elementary courses with as many as 50 participants are condensed into continuation courses attended by fewer 
participants. My courses comprise both linguistics and elements related to Japanese society, high culture and customs. The elementary course Japanese 1 provides students with the crucial first contact with Japanese studies. At this stage some of the students become passionate about studying more, whereas others realise they prefer to concentrate on other subjects.

The survey for this study was conducted at the beginning of the autumn term 2013 with the Japanese 1 course participants. A link to a questionnaire including 13 questions was emailed to the student group. My aim was to examine course participants' backgrounds, studies and employment by analysing specific student cohorts, which would allow me to develop course content that optimally meets students' needs.

The purpose of the questionnaire was to analyse the learners' backgrounds and to find out why they had chosen to study Japanese. The survey clarified from which faculties the students came to the elementary course, as well as their major subjects. A further aim was to find out whether the motivation for choosing Japanese was connected to the students' plans for the future. The survey also throws light on the participants' language choices and language skills in general.

In the future, the same student cohort will be asked to respond to additional questions. The follow-up studies will provide an overall picture of the role of Japanese studies in, for example, students' employability. The present, first part of the study will provide a basis for later studies: the results and the problems observed in phrasing the questions will enable us to reformulate and improve the questionnaires.

\section{Motivation and choice of language}

The focus of this study was on clarifying the choice of language and the initial motivation of a specific student cohort, with the aim of finding out why Japanese is studied in Finland. 
The choice of language can be regarded as a direct consequence of motivation. Dörnyei (2001) defines motivation as follows: motivation means choosing a specific activity and committing oneself to this activity. Motivation, Dörnyei (2001) suggests, can thus explain a person's reasons to act, the duration of the activity and how persistently the person continues the activity.

My aim was to analyse the motivation of students who had recently begun an elementary course in Japanese. However, it is also necessary to consider the various phases of the motivation process. At the beginning of an elementary course, motivation has already developed past the planning and goal-setting phases, but has not yet proceeded to the phases that include implementing and controlling the activity and evaluating the results. Students' motivation varies while studying a foreign language and even during one single course (Dörnyei 2001).

In this article I concentrate particularly on the first phase of motivation, where students have no exact idea of what the studies will require of them. They have expectations regarding their own success and define the value of their expected success. The more probable and important students consider their success to be, the higher their motivation is. At later phases, it is also essential to sustain interest and arrange time and resources for the studies (Dörnyei 2001; Ushioda 2001). The latter factors may explain why motivated students occasionally interrupt their courses. Initial motivation is one of the main themes in this article: even learners who initially seem very motivated may drop out from the course. This phenomenon is also highlighted by Williams and Burden (1997) and by Matsumoto and Obana (2001).

A positive motivational factor for Finns studying Japanese as a foreign language is that both languages are non-Indo-European and even share some structural similarities (Pensikkala 2010a). Moreover, the Japanese phonetic system is rather easily approachable for Finnish learners. Nevertheless, the Japanese language can also create a strong case of culture shock in Finnish learners (Matsumoto \& Obana 2001). This can either reduce or increase a learner's motivation, depending on the individual. Difficulties related to the Japanese 
writing system are clearly a factor that reduces motivation. These positive and negative motivational factors play an important role in determining whether students continue or interrupt their Japanese studies. In addition, students' prior knowledge of Japanese - or of different languages, in general - affects their expectations regarding success in Japanese studies as well as their commitment to these studies. Realistic expectations regarding one's possibilities to complete the studies are factors that enhance motivation (Matsumoto \& Obana 2001).

Internal and external motivational factors are significant for the choice of language and for language studies. Williams and Burden (1997) have drafted a tripartite approach to the concept of motivation, first through external factors. Such external factors as the educational system and study arrangements affect students' instrumental orientation. Instrumental orientation means that the utilitarian viewpoints of learning are emphasised, and orientation is a factor that affects motivation. Instrumental orientation contributes to the development of external motivation. On the other hand, such internal factors as the personal relevance of the content to be learned, feelings of competence, attitudes, age and confidence, have an impact on the development of integrative orientation. Integrative orientation refers to the desire of the learner to identify with the culture of the studied language. This results in the development of inner motivation.

The dichotomy between internal and external motivation has been criticised because it was developed for a specific bilingual context and is not viably applicable to several other contexts (Julkunen 1998). In compliance with Williams and Burden's (1997) views, the problematic nature of the dichotomy is taken into consideration in this study, recognising the simultaneous existence of internal and external motivation. An individual's motivational type focuses more on one of the two, and the emphasis may vary within the different subareas of motivation even for the same individual.

Examples of changes in motivation have been presented by Matsumoto and Obana (2001), who examined students of Japanese in Australia. Their research reveals that during these students' studies their interest in conducting business 
with the Japanese has relatively decreased, whereas their interest in Japanese culture has grown. Moreover, the participants of elementary courses have commonly expressed their interest in business activities, but those who have proceeded to the continuation course have shown less interest. On the other hand, Matsumoto and Obana (2001) state that students who had planned to interrupt their Japanese studies had ultimately decided to continue, guided by their external motivation, in other words, the potential benefits of Japanese to their future careers.

An interest in business activities with the Japanese can, at least to some extent, be regarded as a sign of external motivation. The significance of external and internal motivation for studies can vary from one stage of the study process to the next, and studying is most effective when both are simultaneously present. Matsumoto and Obana (2001) also emphasise that, because of the extensive and diversified connections between Australia and Japan, many Australians begin to study Japanese based on external motivation. However, internal motivational factors develop later side by side with the external ones. In Finland, the situation is different: beginning students typically have an internal motivation alone, or together with external motivation.

These observations highlight the importance of analysing the development of the same student population also after the elementary course. My intention is to pursue this analysis later, while in this study I have limited my focus to students who have only recently begun to study Japanese.

\section{Research method and material}

A questionnaire was used to map students' background data, language choices with their reasons, and future plans. The questionnaire was first tested in a 2013 summer course, after which some of the questions were modified. In the autumn of 2013, the target group consisted of 53 students who had registered for the Japanese 1 course at the University of Jyväskylä Language Centre. The survey was conducted via a questionnaire on the internet-based platform Webropol, to 
which I sent a link to the target group. After three reminders about answering the questionnaire, responses were received from 39 students.

The questionnaire included 13 questions, most of them multiple-choice questions. In some of them, students could choose more than one option, and some were open-ended, allowing the respondents to answer in their own words. The questions provided information on the participants' first year of enrolment at the university, faculty, major subject, minor subjects, first year of Japanese studies at the university, and reasons for beginning to study Japanese. In addition, the respondents were asked whether they were pursuing the basic studies in Japanese, what other languages they studied or spoke, whether they had plans for practical training or student exchange in Japan, and what preliminary ideas they had about employment.

I classified and processed the data by faculty and major subject, as well as based on whether the students answered that Japanese was an advantage in their major subject area, whether their initial aim was to complete the basic studies, and whether they wished to be employed precisely in Japan. In February and March 2014, I processed the data on the Webropol platform by creating tables based on different filters. All the students who had registered for the autumn 2013 Japanese course were emailed another questionnaire in March 2014 in order to determine the reasons for potential interruptions. In addition, the 34 students who had begun another elementary course in May 2014 were asked to submit short essay answers about their reasons for attending the course. This data on study motivation complements the original survey. I processed the complementary data during the summer of 2014 by analysing the open-ended essay answers.

\section{Results}

\subsection{Respondents' background data}

Table 1 shows the respondents' distribution by faculty or higher education institution according to the main survey of 2013. 
Table 1. Number of respondents in the 2013 survey according to faculty/educational institution

\begin{tabular}{|l|l|}
\hline Faculty & Number of respondents \\
\hline Faculty of Humanities & 14 \\
\hline Faculty of Information Technology & 10 \\
\hline Faculty of Mathematics and Science & 8 \\
\hline Faculty of Social Sciences & 2 \\
\hline Faculty of Sport and Health Sciences & 1 \\
\hline Faculty of Education & 1 \\
\hline Jyväskylä University School of Business and Economics & 1 \\
\hline JAMK University of Applied Sciences & 1 \\
\hline Unknown faculty & 1 \\
\hline Total & 39 \\
\hline
\end{tabular}

The respondent numbers correlated to some extent with the number of students in the various faculties of the University. In 2012, the Faculty of Humanities, with its 2,495 students, was the largest of the seven faculties. The second-largest was the Faculty of Mathematics and Science with 1,993 students in 2012, and the Faculty of Information Technology the fifth largest with 1,613 students in the same year (Pöyhönen \& Oikari 2013). Table 2 below shows the distribution of respondents by major subject and faculty in the main survey of 2013 and the complementary survey of 2014.

\subsection{Language repertoire}

A slim majority, that is, 21 of the respondents in the 2013 survey, did not study (or had not previously studied) any elective language besides Japanese at the university. French had been studied by 6 respondents and Chinese by 5 . A small number of the respondents had completed elective courses of English, Spanish, Latin, Swedish, German, Russian and Finnish sign language.

The question about proficiency in languages taught outside of the university highlighted particularly French skills, in addition to English and Swedish. For the rest, the language backgrounds echoed the results presented in the previous paragraph. 
Table 2. Respondents' background data: number of respondents for each major subject and faculty

\begin{tabular}{|c|c|c|c|}
\hline $\begin{array}{l}\text { Faculty } \\
\text { and major subject }\end{array}$ & \begin{tabular}{|l|} 
Number of \\
respondents \\
in 2013
\end{tabular} & \begin{tabular}{|l|} 
Number of \\
respondents, \\
complementary \\
survey in 2014
\end{tabular} & $\begin{array}{l}\text { Number of } \\
\text { respondents, } \\
\text { total of } 2013 \\
\text { and } 2014 \\
\end{array}$ \\
\hline $\begin{array}{l}\text { Faculty of Humanities } \\
\text { History } \\
\text { English } \\
\text { Ethnology } \\
\text { Finnish sign language } \\
\text { Intercultural communication } \\
\text { Romance philology } \\
\text { Finnish } \\
\text { Russian language and culture } \\
\text { Literature }\end{array}$ & $\begin{array}{l}4 \\
2 \\
2 \\
2 \\
1 \\
1 \\
1 \\
1\end{array}$ & 3 & 14 and 3 \\
\hline $\begin{array}{l}\text { Faculty of Social Sciences } \\
\text { Management and leadership } \\
\text { Social sciences of sport } \\
\text { Sociology } \\
\text { Political science } \\
\text { Psychology }\end{array}$ & $\begin{array}{l}1 \\
1 \\
1 \\
1\end{array}$ & $\begin{array}{l}1 \\
1\end{array}$ & 4 and 2 \\
\hline $\begin{array}{l}\text { Faculty of Information Technology } \\
\text { Information systems science } \\
\text { Mathematical information technology }\end{array}$ & $\begin{array}{l}5 \\
5\end{array}$ & $\begin{array}{l}4 \\
9\end{array}$ & 10 and 13 \\
\hline $\begin{array}{l}\text { Faculty of Sport and Health Sciences } \\
\text { Physiotherapy }\end{array}$ & 1 & & 1 \\
\hline $\begin{array}{l}\text { Faculty of Education } \\
\text { Special education }\end{array}$ & 1 & & 1 \\
\hline $\begin{array}{l}\text { Faculty of Mathematics and Science } \\
\text { Chemistry } \\
\text { Physics } \\
\text { Aquatic sciences } \\
\text { Mathematics } \\
\text { Cell and molecular biology } \\
\text { Unknown major subject }\end{array}$ & $\begin{array}{l}3 \\
2 \\
1 \\
1 \\
1 \\
1\end{array}$ & $\begin{array}{l}5 \\
7 \\
2\end{array}$ & 8 and 14 \\
\hline $\begin{array}{l}\text { Jyväskylä University School } \\
\text { of Business and Economics } \\
\text { Accounting }\end{array}$ & & 1 & 1 \\
\hline $\begin{array}{l}\text { Other educational institutions } \\
\text { JAMK University of Applied Sciences, } \\
\text { Degree Programme in Tourism } \\
\text { Upper secondary vocational } \\
\text { school / tourism industry }\end{array}$ & 1 & 1 & 1 and 1 \\
\hline Total & 39 & 34 & 73 \\
\hline
\end{tabular}


The students attending the Japanese elementary course can be said to represent a broad language repertoire. The respondents who majored in history, chemistry and information systems science possessed particularly broad language repertoires. In addition, a few individual respondents had studied or knew several languages. This can be interpreted such that students who know a non-mainstream or otherwise less common language tend to choose a less commonly taught language also later.

To some extent, it seems that multilingualism was concentrated in a smaller group than could be presumed by analysing the overall survey level or faculty level. Nevertheless, the survey demonstrated that for some of the respondents, Japanese was the first less commonly taught language. Japanese elementary courses thus attract both students who have narrow language repertoires and those with broad ones. The respondents majoring in history and information systems science, in addition to knowing several languages, highlighted the usefulness of Japanese skills in their major subject area.

\subsection{Reasons for choosing to study Japanese at the university}

The most common reasons for choosing Japanese studies at the University of Jyväskylä Language Centre were the respondent's other interests related to Japan. This is also demonstrated in Table 3, which will be analysed in detail later.

Table 3. Reasons for choosing to study Japanese at the University Language Centre

\begin{tabular}{|l|l|}
\hline I wanted to learn one more foreign language. & 15 \\
\hline $\begin{array}{l}\text { I wanted to continue the language } \\
\text { studies I had begun earlier. }\end{array}$ & 13 \\
\hline $\begin{array}{l}\text { I wanted to learn some less commonly taught language } \\
\text { and happened to choose Japanese. }\end{array}$ & 7 \\
\hline I have other interests related to Japan. & 29 \\
\hline Japanese is useful in my major subject area. & 11 \\
\hline Other, what? & 6 \\
\hline
\end{tabular}




\subsection{Students' general achievement goal orientation}

The distribution of answers was interesting when the students were asked about their plans to complete the entire basic studies in Japanese or only individual courses. Approximately half of the respondents (20) stated having even initially intended to complete the whole module. Among these respondents, the students of history and mathematical information technology constituted the largest groups.

Those who responded that they intended to complete the basic studies were also the ones most interested in practical training and/or student exchange in Japan. Of the 20 students aiming at the basic studies, nearly all (19) said they were interested in student exchange and 14 also in practical training. We can assume that these 14 learners constitute the most motivated group in the course because they have clear goals. I will focus on analysing this motivated group more thoroughly. Is there a connection between these students' elementary course grades and high motivation?

Within the group of 14 respondents assumed to be the most motivated, 7 had an excellent course grade. Because of some of the following factors, the remaining 7 respondents had no final course grades: one of them left the course based on the recognition of prior learning, one did not attend the course after the initial course meeting, one received a failing grade and did not improve it later, and four interrupted the course.

In March 2014, an inquiry was emailed to the students who had been assumed to be the most motivated but had still interrupted the course. Answers were received from 5 of them explaining their reasons for the interruption. The 2 respondents classified as the most motivated explained that fitting the Japanese course into their other studies had been difficult ${ }^{2}$. In accordance with my earlier

\footnotetext{
2. An analysis of all the course dropouts highlighted the following reasons: 4 could not match the course into their schedule because the lessons were arranged too frequently and only in the evening; 2 explained that illness had prevented them from following the course; 1 said having experienced pair and group work as stressful; 4 of the 5 course dropouts expressed their willingness to complete the course later, highlighting their interest in studying Japanese further.
} 
observations, arranging time and other resources for studies is a central element at a later stage of the motivational process (Williams \& Burden 1997: 121).

There were 4 respondents who answered that they intended to complete the entire basic studies module and wanted to find employment in Japan. One of them told of having chosen Japanese because of the desire to learn one more new language. Of these 4 respondents, 3 had studied Japanese before coming to the elementary course, and 3 of them also said they had other interests in Japan. Japanese skills were experienced as useful in the major subject area by 2 respondents.

The desire to learn one more new language was a relatively strong motivational factor when deciding to attend the Japanese course, as 14 respondents had included it in their answers. Most of these respondents were from the Faculty of Humanities (4) and the Faculty of Information Technology (5).

For a significant part of the respondents, the reason for choosing to study Japanese was linked to their other interests in Japan. This was the case with 11 students from the Faculty of Humanities; 9 from the Faculty of Information Technology; 5 from the Faculty of Mathematics and Science; and 1 each from the faculties of Education, Sport and Health Sciences, and Social Sciences.

Several respondents identified further reasons for choosing to study Japanese in their open-ended answers for the 2013 main survey and the 2014 complementary survey. Reasons other than career-related ones were commonly mentioned in the open-ended answers. The aim to complete the basic studies in Japanese, planned or agreed exchange studies and stays in Japan, a general interest in languages or precisely in the Japanese language and culture, and hobbies related to Japan were mentioned in several answers.

The impact of Japanese popular culture on the choice of language was mentioned by 11 respondents. A few of the respondents indicated it as the only reason, but for most it was a contributory factor. The observations made by Dörnyei and 
Clément (2001) about the emotional attachment present in the acquisition of foreign languages also explain the strong influence of hobbies, dreams for the future, personal interests and goals for choosing to study Japanese. The choice of a foreign language, commitment to studying, and language acquisition are mainly guided by emotions. Positive feelings toward the target language community and the desire to engage in social interaction with the linguistic community of the target language as well as other foreign languages, are the strongest factors determining the choice of language and study motivation (for more on emotional attachment and language learning, see Dörnyei 2001; Dörnyei \& Clément 2001; Ushioda 2001).

Sari Pöyhönen, professor at the University of Jyväskylä Centre for Applied Language Studies, states that studying Japanese can be regarded as a stronger demonstration of identity than studying a more commonly taught language: Japanese studies require more initiative. Those in Finland who want to study such less commonly taught languages as Japanese must independently find out where it can be studied (Pensikkala 2010b).

Even though the opportunities for direct social interaction with representatives of the target language are restricted in Finland, indirect contacts are strong. Through various media channels, students can use their Japanese skills extensively even on a daily basis. In this context, the various media encompass games, music, television programmes and films available via the internet, along with other online resources. The active utilisation of language skills and contacts with the target language enhance students' confidence, which is one constituent of motivation. Study motivation is fundamentally social, even though studying a language, as such, is an academic activity (Clément, Dörnyei \& Noels 1994; Matsumoto \& Obana 2001).

The results of this survey also comply with the findings of Julkunen's (1998) research on the motivation and language choices of students who study foreign languages. A communicative motivation including cognitive features seems to be crucial in the choice of language studies. Language and culture studies are a means of satisfying one's curiosity about a specific linguistic area as well as 
of learning and exploring an uncommon language. A motivation of this type manifests a deep inner motivation for studies.

In a report by Leppänen et al. (2013), curiosity is mentioned as an important characteristic of future international experts. This report defines curiosity as the understanding of people's different intentions, which contributes to the recognition of what is essential, for example, in studies or work.

As the report explains, feeding one's curiosity enhances problem-solving skills and the ability to perceive the implications of one's own activities. Curiosity and a spontaneous, emotional search for challenges ensure satisfaction with one's career choice even after graduation. A curious individual discovers the ways in which to utilise acquired skills in a variety of environments.

The explicit curiosity observed in the students of this survey should also be supported. Being curious together could more clearly be one of the threads in our future Japanese courses. Phenomena that students find meaningful should be increasingly handled in Japanese lessons. It is no longer relevant to define some topics as important and academic, and others as light and leisure-related. The different dimensions of life are increasingly interwoven, and so-called light matters may become extremely meaningful. It thus has to be asked if today's organised studies are still too distant from the learning that occurs in our leisure time and satisfies our curiosity.

Leppänen et al. (2013) also suggest that an international expert used to be defined as a person who possesses both language skills and cultural skills, in addition to being mobile. However, those international experts who have not participated in student exchange or worked abroad should also be recognised. They are consumers of international media, often also produce content, and are involved in global-level daily interaction. These international experts themselves, as well as employers, should be aware of this often tacit know-how.

Furthermore, present-day and future international experts are able to think beyond their own spheres of experience. They also use their free time for learning 
and developing their skills as well as act in different communities, irrespective of language or location. The strong international competence hidden beyond the structures of society should be brought out (Leppänen et al. 2013). All these qualities can also be identified in the participants of this survey. It would be important to articulate this competence for the students themselves as well, so that they could develop and express it, for instance, in different professional contexts.

Not all the respondents in this survey explicitly stated that they studied Japanese for pragmatic reasons, such as for the world of work. On the other hand, some stated having pragmatic reasons in addition to other motives, or as the only reason, for studying Japanese. A problem in this survey, as well as more generally, is the excessively narrow idea of the benefits of language and cultural skills. If the questions in this survey had taken into consideration a broader vantage point, more participants would have responded that knowing Japanese was useful to them. Japanese studies should more clearly have been defined as parts of international knowledge and skills, which would have made them appear as more beneficial to the respondents.

\subsection{Pragmatic reasons for studying Japanese}

The data collected in 2013 indicates that 11 respondents regarded Japanese skills as useful for their major subject or field. The subjects or fields mentioned were ethnology (1), history (2), information systems science (2), mathematical information technology (3), the Master's Degree Programme in Intercultural Communication (1), the Degree Programme in Tourism at JAMK University of Applied Sciences (1), and an unknown major subject in the Faculty of Mathematics and Science (1).

It seems that those who have an external motivation and consider Japanese skills important for their major subject are motivated to study Japanese. When comparing the answer "Japanese is useful in my major subject area" to the respondents' course grades, it was noticed that 8 of the 11 respondents who had regarded Japanese as useful had excellent course grades. Those who 
answered having studied Japanese already before the elementary course also succeeded well, as could be expected: 9 of the 13 respondents had excellent course grades.

The pragmatic arguments for studying Japanese also included the respondents' statements about their interest in exchange studies and practical training in Japan.

\subsection{Employment outlook after graduation}

The participants' interests in an international career or vague career desires were typical of all the survey answers related to employment. An international career was mentioned by 9 respondents from the Faculty of Humanities, 6 from the Faculty of Mathematics and Science, 2 from the Faculty of Social Sciences, and 2 from the Faculty of Information Technology. Vague career desires were highlighted in the answers of 8 respondents from the Faculty of Humanities, 6 from the Faculty of Information Technology, and 2 from the Faculty of Mathematics and Science.

However, 5 respondents expressed the desire to find employment in Japan. Their distribution was as follows: the Faculty of Information Technology (2), Humanities (1), Sport and Health Sciences (1), and Mathematics and Science (1).

The findings comply with those of Mäkinen (2004), who concluded that students' idea of their future profession typically becomes clearer during the third and fourth academic year, in other words, during the intermediate and advanced studies. The chosen minor subject studies also contribute to this process. The majority of respondents in this survey were first- or second-year students, which is why their unclear ideas about future employment were an anticipated result.

In addition to the answers obtained via the main survey in 2013, the open-ended answers by participants in the spring 2014 elementary course cast more light 
on their reasons for attending the course as well as on their motivation. In the 2014 course, 34 participants described their motivation, and some examples of their answers are presented in this context. The demand for Japanese in the world of work is mentioned in the following answers:

"I'm studying physics, and in my future work I will meet a lot of different people. I may even end up undertaking research with Japanese researchers" (Student from the Faculty of Mathematics and Science, 2014).

"...Of course, it would be awesome if this were the language that opens doors to future employment" (Student from the Faculty of IT, 2014).

"In the studies of political science, the University of Jyväskylä requires that I complete courses in two foreign languages. I thought I'd try a less commonly taught language [...] because it is useful if I happen to apply for a diplomat training programme or an international job" (Student from the Faculty of Social Sciences, 2014).

These answers demonstrate an awareness of the need to be able to work in diverse work environments and examine the world from multiple perspectives. The objective of studies is to develop broad-based expertise even though there would be no exact idea of one's future employment. These findings are also in line with Mäkinen (2004). Listing professional goals and future benefits as a reason for beginning a language course implies the recognition of future professional needs as well as dreams and expectations. The mental image of one's future career is always to some extent emotional (Järvi 1997). The emotional attachment that colours foreign language studies is thus present also here.

The world of work requires diverse language skills. Even though English would be used in official contexts, the language of the collaboration partner is needed in other contexts and in leisure time. The proficiency of Japanese is important in unofficial situations because they are ultimately also parts of official processes. Furthermore, language skills are essentially related to intercultural competence, which is a definite prerequisite for successful operation in East Asia even with 
the help of interpreters. In working life, strong subject matter competence and, for example, English skills are the main requirements. In addition to them, one should possess sufficient knowledge of the target country's language and culture. This is the formula for success created by Petteri Kostermaa, who has worked, for example, as Finnair's sales director in Southeast Asia and who also has long and extensive work experience in Japan. Kostermaa's view is shared by several other Finnish experts in science, business and the arts. Examples of experts with strong work experience in Japan include Marko Karppinen, CEO of KONE Japan Co. Ltd; Johan Lindén, Lecturer in Physics at Åbo Akademi; and Yrjö Sotamaa, Professor Emeritus at Aalto University (Riikonen 2010; Valsta 2010; Vihko 2010a, 2010b).

I would like a similar view of linguistic and cultural knowledge to spread among my students as well. Extensive knowledge of Japanese language and culture is not a requirement for all, as even a limited amount of Japanese studies can be sufficient and useful in working life when combined with broad competence in one's own special field.

\section{Conclusions}

There seems to be no single background factor that explains the choice of language or motivation to study Japanese. However, the emotional factors behind the choice and related commitment to studies are clearly highlighted in the results. Instead of external, pragmatic grounds, most respondents identified personal interests and emotional reasons for beginning Japanese courses at the Language Centre. The knowledge of a less commonly taught language and culture may actually become one of the keys for a student's identity and future professional identity.

Follow-up studies on the theme would be necessary, focusing on continuation courses as well as on those participants who interrupt their studies. This would make it possible to obtain more generalisable information on the relationship between background data and the studies, employment and general identity 
formation related to Japanese skills. Analysing the connections between motivation, course interruption and learning outcomes proved stimulating and fruitful in this survey, which indicates the need for further research.

The generalisability of the findings in this study is limited because the sample only included participants from two courses, and the number of respondents was rather low. The questionnaire consisted of 13 questions, which is why specifying inquiries will be needed later, as well as analyses of new populations, in order to create a more comprehensive picture. Some questions related to motivation were rather general and will be complemented later by adding, for example, the possibility to provide open-ended answers.

My aim as a teacher is to allocate course content so that it will meet students' individual needs in increasingly effective ways. The learners should be made aware of their own international competence by explicitly considering the following aspects in future Japanese courses: understanding Japanese proficiency as a part of broader international competence, integrating more personal and hobby-related interests with academic contexts in concrete learning situations, and nurturing a generally curious attitude.

\section{Acknowledgement}

This article has been translated from Finnish by Sirpa Vehviläinen.

\section{References}

Cairns, J. 2010. Kieliosaamisen kehittäminen vaatii resursseja. Juha Janhusen haastattelu. In O. Smedlund \& Y. Uemura (eds.), Japanin kieli Suomessa. Helsinki: Yliopistopaino, 55-56.

Clément, R., Dörnyei, Z. \& Noels, K. 1994. Motivation, self-confidence, and group cohesion in the foreign language classroom. Language Learning, 44 (3), 417-448. doi:10.1111/j.1467-1770.1994.tb01113.x

Dörnyei, Z. 2001. Teaching and researching motivation. Harlow: Pearson Education Limited. 
Dörnyei, Z. \& Clément, R. 2001. Motivational characteristics of learning different target languages: results of a nationwide survey. In Z. Dörnyei \& R. Schmidt (eds), Motivation and Second Language Acquisition. Honolulu: University of Hawaii Press, 399-432.

Julkunen, K. 1998. A2-kielen opiskelijoiden motivaatio ja kielivalinta. Joensuu: Joensuun yliopistopaino.

Järvi, P. 1997. Ammattimielikuva. Ammattimielikuva osana ammatillisen suuntautumisen prosessia. Turku: Turun kauppakorkeakoulun julkaisuja.

Leppänen, J., Lähdemäki, J., Mokka, R., Neuvonen, A., Orjasniemi, M. \& Ritola, M. 2013. Piilotettu osaaminen. Helsinki: Demos Helsinki.

Matsumoto, M. \& Obana, Y. 2001. Motivational factors and persistence in learning Japanese as a foreign language. New Zealand Journal of Asian Studies, 3 (1), 63-82.

Mäkinen, M. 2004. Mikä minusta tulee "isona"? Yliopisto-opiskelijan ammattikuvan kehittyminen. In P. Tynjälä, J. Välimaa \& M. Murtonen (eds.), Korkeakoulutus, oppiminen ja työelämä. Juva: PS-kustannus, 57-75.

Pensikkala, J. 2010a. Riikka Länsisalmi haluaa kirjoittaa Japanista suomeksi. Riikka Länsisalmen haastattelu. In O. Smedlund \& Y. Uemura (eds.), Japanin kieli Suomessa. Helsinki: Yliopistopaino, 65-68.

Pensikkala, J. 2010b. Monipuolisen kielikoulutuksen puolestapuhuja. Sari Pöyhösen haastattelu. In O. Smedlund \& Y. Uemura (eds.), Japanin kieli Suomessa. Helsinki: Yliopistopaino, 69-72.

Pöyhönen, M. \& Oikari, R. (eds.) 2013. Humanistinen tiedekunta vuosikertomus 2012. Jyväskylä: Jyväskylän yliopistopaino.

Riikonen, A. 2010. Tutkijana Japanissa. Johan Lindénin haastattelu. In O. Smedlund \& Y. Uemura (eds.), Japanin kieli Suomessa. Helsinki: Yliopistopaino, 211-214.

Smedlund, O. \& Uemura, Y. (eds.) 2010. Turussa toivotaan Aasia-yhteistyötä korkeakoulujen välille uuden sukupolven kasvattamiseksi. Annamari Konttisen, Outi Luovan ja Annukka Kinnarin haastattelu. Japanin kieli Suomessa. Helsinki: Yliopistopaino, 207-210.

Ushioda, E. 2001. Language learning at university: exploring the role of motivational thinking. In Z. Dörneyi \& R. Schmidt (eds.), Motivation and Second Language Acquisition. Honolulu : Second Language Teaching \& Curriculum Center, University of Hawai' $i$ at Mānoa, 103-106.

Valsta, S. 2010. Jousiammuntaa saa toki työn ohessa harrastaa -jos siihen jää aikaa. Marko Karppisen haastattelu. In O. Smedlund \& Y. Uemura (eds.), Japanin kieli Suomessa. Helsinki: Yliopistopaino, 127-130. 
Vihko, T. 2010a. Japanin-kaupassa kielitaito on valttia. Petteri Kostermaan haastattelu. In O. Smedlund \& Y. Uemura (eds.), Japanin kieli Suomessa. Helsinki: Yliopistopaino, 135-138. Vihko, T. 2010b. Ei siihen tarvita kuin yksi ihminen. Yrjö Sotamaan haastattelu. In O. Smedlund \& Y. Uemura (eds.), Japanin kieli Suomessa. Helsinki: Yliopistopaino, 223-226.

Williams, M. \& Burden, R. 1997. Psychology for language teachers. Cambridge: Cambridge University Press. 


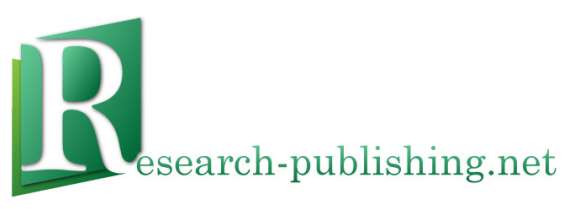

Published by Research-publishing.net, not-for-profit association Dublin, Ireland; Voillans, France, info@research-publishing.net

(C) 2015 by Research-publishing.net (collective work)

Each author retains their own copyright

Voices of pedagogical development - Expanding, enhancing and exploring higher education language learning Edited by Juha Jalkanen, Elina Jokinen, \& Peppi Taalas

Rights: All articles in this collection are published under the Attribution-NonCommercial -NoDerivatives 4.0 International (CC BY-NC-ND 4.0) licence. Under this licence, the contents are freely available online (as PDF files) for anybody to read, download, copy, and redistribute provided that the author(s), editorial team, and publisher are properly cited. Commercial use and derivative works are, however, not permitted.

\section{()ㅛ $\Theta \Theta$}

Disclaimer: Research-publishing.net does not take any responsibility for the content of the pages written by the authors of this book. The authors have recognised that the work described was not published before, or that it is not under consideration for publication elsewhere. While the information in this book are believed to be true and accurate on the date of its going to press, neither the editorial team, nor the publisher can accept any legal responsibility for any errors or omissions that may be made. The publisher makes no warranty, expressed or implied, with respect to the material contained herein. While Research-publishing.net is committed to publishing works of integrity, the words are the authors' alone.

Trademark notice: Product or corporate names may be trademarks or registered trademarks, and are used only for identification and explanation without intent to infringe.

Copyrighted material: Every effort has been made by the editorial team to trace copyright holders and to obtain their permission for the use of copyrighted material in this book. In the event of errors or omissions, please notify the publisher of any corrections that will need to be incorporated in future editions of this book.

Typeset by Research-publishing.net

Cover design by (C) Antti Myöhänen

ISBN13: 978-1-908416-25-4 (Paperback - Print on demand, black and white)

Print on demand technology is a high-quality, innovative and ecological printing method, with which the book is never 'out of stock' or 'out of print'.

ISBN13: 978-1-908416-26-1 (Ebook, PDF, colour)

ISBN13: 978-1-908416-27-8 (Ebook, EPUB, colour)

Legal deposit, Ireland: The National Library of Ireland, The Library of Trinity College, The Library of the University of Limerick, The Library of Dublin City University, The Library of NUI Cork, The Library of NUI Maynooth, The Library of University College Dublin, The Library of NUI Galway.

Legal deposit, United Kingdom: The British Library.

British Library Cataloguing-in-Publication Data.

A cataloguing record for this book is available from the British Library.

Legal deposit, France: Bibliothèque Nationale de France - Dépôt légal: septembre 2015. 